\title{
EDUKASI CARA PENGGUNAAN ANTIBIOTIK YANG BAIK DAN BENAR DENGAN METODE CARA BELAJAR INSAN AKTIF PADA KADER POSYANDU DI KELURAHAN JAWA
}

\author{
Octaviana Maria Simbolon \\ Program Studi Strata I Farmasi STIKES Dirgahayu Samarinda \\ Jl. Pasundan No. 21, Kelurahan Jawa, Kecamatan Samarinda Ulu \\ e-mail: octavianasimbolon@gmail.com
}

\begin{abstract}
ABSTRAK
Posyandu sudah menjadi kebutuhan masyarakat saat ini maupun di masa yang akan datang. Kader Posyandu adalah anggota masyarakat yang mau bekerja secara sukarela dan mau meluangkan waktunya untuk melaksanakan kegiatan. Kader dituntut memiliki pengetahuan khususnya mengenai kesehatan dan juga tentunya pengetahuan umum. Untuk mencegah terjadinya resistensi antibiotik pada masyarakat di Kelurahan Jawa, maka Kader Posyandu seharusnya dibekali dengan berbagai pengetahuan khususnya pengetahuan tentang cara penggunaan antibiotik yang baik dan benar. Metode kegiatan yang dilakukan berupa metode CBIA (Cara Belajar Insan Aktif). Metode CBIA tentang cara penggunaan antibiotik yang baik dan benar serta bahaya resistensi antibiotik dilakukan dengan cara mengelompokkan ibu-ibu dengan anggota 5-10 orang tiap kelompok. Berdasarkan hasil pre-test dan post-test menunjukkan responden dengan kategori baik meningkat menjadi 86\%. Hal ini membuktikan bahwa edukasi penggunaan antibiotika dengan metode CBIA sangat efektif untuk meningkatkan pengetahuan masyarakat mengenai penggunaan antibiotika yang baik dan benar. Saran bagi program kemitraan selanjutnya adalah penjelasan mengenai golongan obat lain yang penting untuk diketahui masyarakat.
\end{abstract}

\section{Kata Kunci : Antibiotik, CBIA, Edukasi, Kader Posyandu}

\begin{abstract}
Posyandu has become a necessity for the community today and in the future. Posyandu cadres are community members who are willing to work voluntarily and are willing to take their time to carry out activities. Cadres are required to have knowledge, especially about health and of course general knowledge. In order to prevent antibiotic resistance from occurring in the people of Jawa Kelurahan, Posyandu cadres should be equipped with various knowledge, especially knowledge about how to use antibiotics properly and correctly. The method of activities carried out is in the form of CBIA method. CBIA method on how to use antibiotics properly and correctly and the dangers of antibiotic resistance is carried out by grouping them with 5-10 members per group. Based on the results of the pre-test and posttest, the respondents in the good category increased to $86 \%$. This proves that education on the use of antibiotics using the CBIA method is very effective in increasing public knowledge about the proper and correct use of antibiotics. Suggestions for the next partnership program are an explanation of other drug classes that are important for the public to know.
\end{abstract}

\section{Key Words : Antibiotics, CBIA, Education, Posyandu Cadres}

\section{PENDAHULUAN}

Kelurahan Jawa mulai dari cikal bakalnya pada tahun 1917 pada jaman pemerintah Hindia Belanda. Kelurahan Jawa merupakan bagian dari pemerintahan Kecamatan Samarinda Ulu. Berdasarkan data dari BPS (Badan Pusat Statistik) Kota Samarinda pada tahun 2017, diketahui bahwa di Kelurahan Jawa terdapat satu (1) rumah sakit, satu (1) puskesmas, 18 posyandu, dua (2) posyandu lansia dan 10 dokter praktek. Di lain hal, berdasarkan data Profil Kesehatan Kota Samarinda pada tahun 2016, jumlah rumah tangga pada tahun 2016 di Kecamatan Samarinda Ulu sebanyak 30.886 rumah tangga.

Kader Posyandu adalah anggota masyarakat yang mau bekerja secara sukarela dan mau meluangkan waktunya untuk melaksanakan kegiatan Usaha 
Perbaikan Gizi Keluarga, serta mampu menggerakkan masyarakat untuk ikut serta dalam kegiatan tersebut. Dalam melaksanakan tugas sebagai Kader Kesehatan di Posyandu, Kader dituntut memiliki pengetahuan khususnya mengenai kesehatan dan juga tentunya pengetahuan umum.

Tingginya penggunaan antibiotika secara tidak tepat dikalangan masyarakat saat ini menyebabkan terjadinya masalah resistensi antibiotika. Penyebab utama resistensi antibiotika ialah penggunaannya yang meluas dan irasional (Utami, 2012). Hasil penelitian Antimicrobial Resistant in Indonesia (AMRIN-Study) terbukti dari 2.494 individu di masyarakat, 43\% Escherichia coli resisten terhadap berbagai jenis antibiotik antara lain: ampisilin (34\%), kotrimoksazol (29\%) dan kloramfenikol (25\%) (Kemenkes, 2011).

Hasil Riset Kesehatan Dasar (Riskesdas) pada tahun 2013 memberikan informasi bahwa 35,2\% rumah tangga menyimpan obat untuk swamedikasi. Sebanyak 35,2\% rumah tangga menyimpan obat dan $35,7 \%$ diantaranya menyimpan obat keras dan antibiotika. Selanjutnya diketahui bahwa $27,8 \%$ di antaranya menyimpan antibiotik, dan $86,1 \%$ antibiotik tersebut diperoleh tanpa resep (Moeloek, 2015).

Pemberian informasi yang benar terkait penggunaan obat menjadi kebutuhan masyarakat agar terhindar dari dampak buruk kesehatan diri maupun lingkungan. Untuk mencegah terjadinya resistensi antibiotik pada masyarakat di Kelurahan Jawa, maka Kader Posyandu seharusnya dibekali dengan berbagai pengetahuan khususnya pengetahuan tentang cara penggunaan antibiotik yang baik dan benar. Kader Posyandu yang telah menerima penyuluhan tersebut diharapkan dapat memberikan edukasi di tengah-tengah ibu rumah tangga tentang bagaimana seharusnya menggunakan antibiotik yang baik dan benar.

\section{METODE}

Metode kegiatan yang dilakukan berupa edukasi CBIA kepada Kader Posyandu (Widayati, 2008). Kegiatan dimulai dengan pre-test dan diakhiri dengan post-test. Edukasi CBIA tentang cara penggunaan antibiotik yang baik dan benar serta bahaya resistensi antibiotik dilakukan oleh apoteker selama \pm 2 jam. Edukasi dilakukan dengan cara mengelompokkan ibu-ibu dengan anggota 5-10 orang tiap kelompok. Selama kegiatan CBIA berlangsung, diskusi antar anggota dimaksimalkan yang didampingi oleh tutor tanpa kegiatan tulis menulis.

Alat dan bahan yang digunakan antara lain adalah leaflet 'Penggunaan Antibiotik yang Baik dan Benar', soal pre-test dan post-test, Cefixime tablet, Cefixime sirup, Amoksisilin tablet, Amoksisilin sirup, Cefadroxyl tablet, Cefadroxyl sirup, Eritromisin tablet, Eritromisin sirup, Cotrimoxazole tablet dan Cotrimoxazole sirup.

\section{HASIL DAN PEMBAHASAN}

Kegiatan dimulai dengan pre-test untuk mengetahui bagaimana persepsi awal dari Kader Posyandu mengenai cara penggunaan antibiotik yang baik dan benar serta bahaya resistensi antibiotik. Hasil pre-test dapat dilihat pada Tabel 1.

Setelah mendapatkan materi edukasi mengenai 'Penggunaan Antibiotik yang Baik dan Benar', maka peserta dikelompokkkan menjadi beberapa kelompok. Kegiatan pertama yang dilakukan yakni mengamati nama dan kekuatan sediaan antibiotik yang tertera pada masing-masing kemasan obat. Kegiatan kedua yakni menjelaskan cara menggunakan antibiotik yang baik dan benar, menjelaskan adanya peringatan efek samping dan kontraindikasi. 
Setelah itu, peserta diberikan posttest. Post-test diberikan untuk mengetahui pemahaman ibu-ibu PKK setelah rangkaian kegiatan penyampaian materi dan edukasi CBIA dengan mengisi kuesioner yang sama dengan saat pre-test. Kegiatan kemudian dilanjutkan dengan sesi diskusi tanya jawab untuk memperdalam pemahaman Kader Posyandu tentang materi tersebut. Hasil post-test dapat dilihat pada tabel 2.

Berdasarkan hasil pre-test dan post-test menunjukkan responden dengan kategori baik meningkat menjadi $86 \%$. Hal ini membuktikan bahwa edukasi penggunaan antibiotika dengan metode CBIA sangat efektif untuk meningkatkan pengetahuian masyarakat mengenai penggunaan antibiotika yang baik dan benar. Masyarakat dapat memahami dan serta dapat meningkatkan kemandirian dan perubahan perilaku dalam memilih dan menggunakan antibiotika secara benar, dan akan meningkatkan penggunaan obat secara rasional sehingga mutu pelayanan kesehatan dapat ditingkatkan.

Tabel 1. Distribusi Pengetahuan saat pre-test pada Kader Posyandu di Kelurahan Jawa

\begin{tabular}{ccc}
\hline Pengetahuan & $\mathrm{n}$ & $\%$ \\
\hline Baik $($ nilai $>75)$ & 4 & 29 \\
\hline Kurang $($ nilai $\leq 75)$ & 10 & 71 \\
\hline Jumlah & 14 & 100 \\
\hline
\end{tabular}

Tabel 2. Distribusi Pengetahuan saat post-test pada Kader Posyandu di Kelurahan Jawa

\begin{tabular}{ccc}
\hline Pengetahuan & $\mathrm{n}$ & $\%$ \\
\hline Baik $($ nilai $>75)$ & 12 & 86 \\
\hline Kurang $($ nilai $\leq 75)$ & 2 & 14 \\
\hline Jumlah & 14 & 100 \\
\hline
\end{tabular}

\section{KESIMPULAN DAN SARAN}

Program Kegiatan Masyarakat (PKM) yang dilaksanakan pada tanggal 7 Februari 2019 bertempat di Kantor Kelurahan Jawa Samarinda dengan judul Edukasi Cara Penggunaan Antibiotik yang Baik dan Benar dengan Metode
CBIA pada Kader Posyandu di Kelurahan Jawa telah terlaksanakan dengan baik dimana terjadi peningkatan pengetahuan Kader Posyandu setelah mengikuti kegiatan ini. Saran bagi program kemitraan selanjutnya adalah penjelasan mengenai golongan obat lain yang penting untuk diketahui masyarakat.

\section{UCAPAN TERIMA KASIH}

Stikes Dirgahayu Samarinda untuk dukungan dalam program kemitraan ini

\section{DAFTAR PUSTAKA}

Badan Pusat Statistik (2017). Samarinda Ulu dalam Angka 2017. Samarinda: BPS Kota Samarinda.

Dinas Kesehatan Kota Samarinda. (2016). Profil Kesehatan Kota Samarinda Tahun 2016. Samarinda Kementrian Kesehatan, B. P. (2013). Riset Kesehatan Dasar. Jakarta.

Kementerian Kesehatan. (2011). Pedoman Umum Penggunaan Antibiotik. Jakarta

Moeloek, N. D. F. (2015). Menkes canangkan gerakan masyarakat cerdas menggunakan obat. http://www.depkes.go.id/article/vie w/15111900001/menkes-

canangkan-gerakan-masyarakatcerdas-menggunakan-obat.html, diakses 18 November 2018

Utami, R.E. (2012). Antibiotika, Resistensi, dan Rasionalitas Terapi. SAINTIS. 1:124-138

Widayati, A., Suryawati, S., Crespigny, C., Hiller, J.E., (2008). Identifying Key Beliefs of Self Medication with Antibiotics in Yogyakarta City Indonesia, http://www.inrud.org, diakses 18 November 2018. 